\title{
FISCAL SNAGS AND THE FAMILY CAREGIVERS OF SCHIZOPHRENICS
}

\section{Social Work}

Sejal Macwan*

\section{Dr. Ninad Jhala}

PhD Scholar, Anand Institute of Social Work, Anand, Affiliated to Sardar Patel University, VV Nagar, Gujarat.*Corresponding Author

Principal, Anand Institute of Social Work, Anand, Affiliated to Sardar Patel University, VV Nagar, Gujarat.

\section{ABSTRACT}

The prevalence of schizophrenia in India is about 3/1000 individuals (Gururaj Girish \& Isaac, 2005). The World Health Report, 2001 states the prevalence of schizophrenia is approximately 24 million people across the globe, which is a shocking revelation. The instances about mental health concerns are increasing day by day. The breakdown in family due to several life changing issues especially recently with COVID-19 (Corona Virus Disease) pandemic has changed almost everything in a person's life. In such circumstances managing and balancing a sound mental health is like an adventure. Family has a crucial role to play in it and a strong family bondage is a bonus to it. Nonetheless, every coin has two sides especially when the dilemma is long lasting like that of schizophrenia, it cripples down the family.

OBJECTIVE: To study economic problems faced by the family caregivers of schizophrenics.

METHOD:A descriptive study was conducted to examine the fiscal snags by the family caregivers of patients and schizophrenia. 200 family caregivers were selected by applying stratified systematic sampling method from the Hospitals for Mental Health operated by Department of Health, Government of Gujarat and a criterion of minimum facility of 100 beds was applied thereto. A structured interview tool was designed for the purpose of present study by referring the Burden Assessment Scale of Thara et.al (1998) and the Zarit Burden Interview.

RESULTS: Most of the respondents strongly agree that their financial conditions are not adequate to look after the care receivers 33 ( $\mathrm{n}=66$ ). Most of the respondent worried for the future financial need of the care receivers $36.5(\mathrm{n}=73)$. Most of the respondents strongly agree the statement that they have never received any form of financial support from other family members is treating the care receiver $33.5(\mathrm{n}=67)$.

\section{KEYWORDS}

\section{Mental Health, Schizophrenia, Pandemic, Family Bondage}

\section{INTRODUCTION:}

Schizophrenia is an immobilizing, long-lasting mental disorder that poses various challenges. It exerts distress not only on the affected individual but also commands immense economic pressure on the entire family of caregivers; nMental Health, Schizophrenia, Pandemic, Family Bondageot to mention the psycho-somatic stress on them and the society at large. This is further aggravated by long-term hospitalization, continuous medication costs and other burgeoning expenditures.

Schizophrenia is a complex disorder that affects $4.7 \%$ of the total mentally ill population of Gujarat as reported by Census 2011, Government of India. This disorder has a considerable impact not only on patients' health and well-being but also on their surrounding environment. The disbursements of the management of the illness remain huge for any social institution, family being the major player therein.

Schizophrenia is a disorder of brain function, affecting one's thoughts, feeling and actions. Warning signs and symptoms develop either gradually or seem snappishly and fluctuate from one disordered person to another. The disorder evolves in cycles of remissions and relapses. Indications contain exile from reality with misbelief formation, hallucinations, emotional deregulation and disordered behaviour. In excess of time, a gradual deterioration in cerebral functioning and societal associations happens. This hints to a noticeable behaviour adaptation, social segregation, working infirmity, reasoning deficiency and deprived healthiness. Schizophrenia is also a major cause of suicide (Carlborg et al., 2010). Presently, there is no healing (curative) conduct (treatment) for schizophrenia (Van O.S. et al., 2006, Andreasen et al., 2005)

The mentally ill person in family is burdened subjectively and objectively both. Both the forms of burden destroy the normal functioning in family. The family member involved in care giving role is suffering a lot in all the spheres of life, especially the financial sphere.

\section{MATERIALS AND METHOD:}

The study at hand was carried out in the Government Hospitals for Mental Health at Ahmedabad and Vadodara cities of Gujarat state. The data collection was carried out across one year period. The core objective of the study was to access financial constraints faced by the family caregivers in caring for the patients and schizophrenia. The data was collected by using stratified systematic sampling method. The sample size for the same was 200 family caregivers. Data was collected in a pre-designed structured Proforma. Data entry and analysis was done in Statistical Package for Social Sciences (SPSS).

\section{REVIEW OF LITERATURE:}

Addo, R. et al. (2018) piloted a study entitled, "Economic burden of caregiver for persons with severe mental illness in sub-Saharan Africa: A systematic review." The purpose behind the research study was to evaluate and examine economic burden of severe mental illness of primary family caregivers of the said region. A standardized tool was utilized for collecting data with the adult caregivers as the respondents in the study. The female were more in numbers representing at-home family caregivers who were mainly unemployed. Economic burden was estimated as miserable among the family caregivers. The causal factors for financial burden were the monetary constraint, loss of source of income and loss of occupation due to members with mental illness in the family. All these dynamics were accountable for deliriously upsetting the state of the family caregivers.

\section{RESULT AND DISCUSSIONS:}

Table-1 Demographic Profile of the Family Care Givers:

\begin{tabular}{|l|l|l|}
\hline Particulars & $\begin{array}{l}\text { Frequency } \\
(\text { N=200) }\end{array}$ & Percentage (\%) \\
\hline Gender & 97 & 48.5 \\
\hline Male & 103 & 51.5 \\
Female & 48 & 24 \\
\hline Education & 44 & 22 \\
\hline Illiterate & 54 \\
Up to Primary Education & 43 & 21.5 \\
Up to Higher Secondary Education & 10 & 05 \\
Graduate & 01 & 0.5 \\
Post-Graduate & 51 \\
Other & 34 & 25.5 \\
\hline Monthly Income & 25 & 17 \\
\hline Less than ₹ 5000 & 13 \\
₹ 5001-₹ 10000 & 19 & 6.5 \\
₹ 10001-₹ 15000 & 51 \\
₹ 15001-₹ 20000 & 0.5 \\
₹ 20001-₹ 25000 & 25.5 \\
More than ₹ 25000 & 3.5 \\
\hline Not Applicable & 87 \\
\hline Relation of Family care giver with patient with schizophrenia \\
\hline Parent & 88 & 44 \\
\hline
\end{tabular}




\begin{tabular}{|l|l|l|}
\hline Sister \& sister in law & 17 & 8.5 \\
\hline Daughter \& daughter in law & 09 & 4.5 \\
\hline Son & 08 & 4 \\
\hline Spouse & 39 & 19.5 \\
\hline Brother & 35 & 17.5 \\
\hline Other & 04 & 02 \\
\hline
\end{tabular}

It can be depicted from the Table-1 that majority of the respondents are females. Looking towards the educational qualifications of the family caregivers, it is displayed in the above table that most of respondents have studied up to higher secondary level. The income column of the respondents reveal that equal number of the respondents i.e. 25.5 percent $(n=51)$ have reported a lowest income in category i.e. less than ₹5000 and the highest income in the category i.e. more than ₹25,000. Looking towards the relationship of family caregivers with the ill family member i.e. patient with schizophrenia, it is revealed that majority of the family caregivers are either mother or father of the ill family member.

Table- 2 Economic Problems of Caregivers of Schizophrenic Patients:

\begin{tabular}{|c|c|c|c|c|c|}
\hline Particulars & \multicolumn{5}{|c|}{ Response } \\
\hline $\begin{array}{c}\text { SA } \\
\text { Family caregiver's current financial } \\
\begin{array}{c}\text { Sosition is not adequate to look after the } \\
\text { patient. }\end{array}\end{array}$ & 21.5 & 24 & 1.5 & 20 & 33 \\
\hline $\begin{array}{c}\text { Family caregiver is worried for future } \\
\text { financial situation }\end{array}$ & 23 & 36.5 & 1.5 & 21.5 & 17.5 \\
\hline $\begin{array}{c}\text { Family's financial situation has worsened } \\
\text { since his/her illness. }\end{array}$ & 16.5 & 11 & 0.5 & 26.5 & 45.5 \\
\hline $\begin{array}{c}\text { Left with no savings to utilize in need for } \\
\text { the family }\end{array}$ & 19 & 29.5 & 1.5 & 25.5 & 24.5 \\
\hline $\begin{array}{c}\text { I have never received any form of financial } \\
\text { support from other family members. }\end{array}$ & 33.5 & 24.5 & 01 & 20.5 & 20.5 \\
\hline
\end{tabular}

* SA: Strongly Agree, A: Agree, N: Neutral, D: Disagree, SD: Strongly Disagree

The Table - II reflects the economic problems encountered by the family caregiver in taking care of patients of schizophrenia i.e. the care receivers. The family caregivers report inadequate current financial position in caring for the patients. A state of worry is also reported by them for the future of patients of schizophrenia in most of the cases. They have also agreed that they are left with no saving for other family members due to the ill family member. Along with this, they also reveal that most of them have not received any form of financial support from other family members.

\section{CONCLUSION:}

It can be concluded from the above study that lower the income, higher economic problems among the family caregivers are observed. The family caregivers who are involved in care giving role are female in major number.

\section{REFERENCES:}

1. Addo, R. Agyemang S.A., Tozan, Y. and Nonvignon J. (2018) Economic burden of caregiver for persons with severe mental illness in sub-Saharan Africa: A systematic caregiver for persons with severe mental illness in sub-Saharan Africa: A system
review. PLOs ONE 13 (8): e0199830. http://doi.org/10.1 37/journal.pone.0199830

2. Davis L.M \& Drummond M.F. The economic burden of schizophrenia. Psychiatry Bulletin 1940;(14): 522-525

3. Davis L.M \& Drummond M.F. Economics and schizophrenia: The real cost. Br. J Psychiatry 1994; (165) Suppl. 25: 18-21

4. https://www.who.int/news-room/ factsheets/ detail/ schizophrenia \# text= Schizophrenia\%20affe cts\% $2020 \% 20$ million\% 20 people, affect $\% 20$ educational $\%$ 20 and $\% 20$ occupational $\% 20$ performance.

5. Sharma, P.K. (2014). Burden in care of patients with schizophrenia: To which extent caregivers suffer. Journal of Pharmaceutical and Scientific Innovation. 3 (6): 522-528. DOI:10.7897/2277-4572.03690. 